\title{
RAPD Analysis of Genetic Variation Within and Among Four Natural Populations of Betula maximowicziana
}

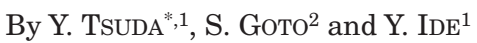

(Received 19 $9^{\text {th }}$ April 2004)

\begin{abstract}
Summary
Betula maximowicziana is a long-lived pioneer tree species in cool temperate forests that plays an important role in the forest ecosystem and has high economic value. Random amplified polymorphic DNA (RAPD) markers were used to evaluate the genetic variation of four natural populations of B. maximowicziana (three in central Honshu and the other in Hokkaido) to obtain fundamental information on this natural resource. Sixty-one reproductive amplified bands were obtained with 23 primers. Of these 61 bands, 22 were monomorphic and 39 were polymorphic. The level of genetic variation within each population may be very similar, because the population rankings according to number of polymorphic loci, Shannon's indices and intra-population genetic variance revealed no definite patterns. Global analysis of AMOVA (analysis of molecular variance) showed that genetic variation among populations accounted for $15.6 \%$ of the total variation, with the remainder $(84.4 \%)$ occurring within population. These results demonstrate that genetic differentiation among the four populations is moderate. Hierarchical AMOVA analysis showed that variation among regions (Hokkaido and central Honshu) accounted for $10.4 \%$ of the total genetic variation, suggesting that regional genetic differentiation is relatively high. Significant correlations between pairwise $\Phi_{\mathrm{PT}}$ values and geographic distance were detected, and results of both a neighbor-joining dendrogram based on pairwise $\Phi_{\mathrm{PT}}$ values, and principal coordinate analysis (PCO) based on a Euclidean metric revealed that the Furano population in Hokkaido was genetically different from the three populations in central Honshu. The data obtained in this study should have important implications for the conservation and management of regional genetic variation of $B$. maximowicziana.
\end{abstract}

Key words: Betula maximowicziana, natural resource, RAPD, regiona genetic variation.

\section{Introduction}

One of the Japanese birches, Monarch birch (Betula maximowicziana), is distributed in the cool temperate zone from the eastern part of Honshu Island to Hokkaido in Japan (ОHWI, 1965). B. maximowicziana is a monoecious species with an outcrossing breeding system involving wind-pollination and wind dispersal of seeds. B. maximowicziana is a pioneer tree species that grows rapidly in open sites, such as gaps, and often establishes even-aged stands (OSUMI and SAKURAI, 1997). Thus, this species plays important roles in the stability and sustainability of forest ecosystems in the cool temperate zone, not only as a

1) Laboratory of Forest Ecosystem Studies, Department of Ecosystem Studies, Graduate School of Agricultural and Life Sciences, The University of Tokyo, 1-1-1 Yayoi, Bunkyo-ku, Tokyo 113-8657. Japan. Tel. +81-3-5841- 8208; Fax +81-3-5841-8259.

2) University Forest in Hokkaido, Graduate School of Agricultural and Life Sciences, The University of Tokyo, Yamabe, Furano, Hokkaido 079-1561. Japan. Tel. +81-167-42-2111; Fax +81-167-42-2689.

*) Corresponding author's present address: YoshIAKI TsUDA, Laboratory of Forest Ecosystem Studies, Department of Ecosystem Studies, Graduate School of Agricultural and Life Sciences, The University of Tokyo, 1-1-1 Yayoi, Bunkyo-ku, Tokyo 113-8657. Japan. Tel. +81-35841-8208; Fax +81-3-5841-8259. E-mail: ytsuda@es.a.u-tokyo.ac.jp major pioneer tree species but also as a long-lived dominant species (WATANABE, 1989). Furthermore, in plantations of Cryptomeria japonica, natural germination or recruitment of $B$. maximowicziana is promoted by artificial disturbance of the soil surface such as clear cutting, site preparation and plantation (HASEGAWA and TAIRA, 2000). These recruited birches can make valuable contributions to forest growth parameters, and may both enhance the public welfare of the forests and provide significant additional natural resources, especially where plantations of $C$. japonica have been unsuccessful for instance in snowy regions (HASEGAWA, 1998; HASEGAWA and TAIRA, 2000).

B. maximowicziana also yields high quality wood, so its use as a commercial crop from natural forests is being promoted nowadays. The decline of natural resources in hardwood tree species, including B. maximowicziana, was predicted in Hokkaido more than 20 years ago (ADACHI et al., 1980). However, little is known about the genetic variation of this species, despite its ecological and economic importance, and the fact that knowledge about genetic variation provides an important baseline for conservation and forest management (GEBUREK, 1997). Moreover, B. maximowicziana seeds or seedlings are being commercially circulated with little or no regard for their provenance now. Thus, there is an urgent need to obtain genetic information on natural populations of B. maximowicziana, before fragmentation of the species occurs through further cutting and plantation, since excessive cutting and plantation can affect the genetic variation in natural populations.

Molecular markers are good tools for the detection of genetic variation within and among populations. Range-wide surveys of genetic variation, based on molecular markers, have now been performed on thousands of species (PETIT et al., 1998). Allozymes, especially, have been examined in many species and provide useful information related to evolution and population genetics (HAMRICK et al., 1992). However, in a previous allozyme analysis of $B$. maximowicziana, in which 13 enzymes were examined, only two loci were detected as useful markers and polymorphism at these two loci was relatively low (KADO et $a l .$, 2002). To evaluate genetic variation, as many loci as possible should ideally be used. Random amplified polymorphic DNA (RAPD) markers (WILLIAMs et al., 1990) allow us to obtain large amounts of data on genetic variation within and among populations without detailed prior knowledge of DNA sequences (HOLSINGER et al., 2002). Furthermore, the practically unlimited number of primers that can be used provide information on variation across the whole genome (RAMSER et al., 1996; GEBUREK, 1997). Moreover, RAPDs have several advantages over allozyme, sequencing and restriction fragment length polymorphism (RFLP) analyses, including speed, low cost, and ease of collection and storage of material (RAMSER et al., 1996; SCHIERENBECK et al., 1997; SAITO et al., 2002). Due to these advantages, RAPD markers have been used for genome mapping, identifying cultivars, breeding and analyzing genetic variation within and among populations (both intra- and interspecies), although RAPDs are dominant markers. In this study, genetic variations within and among $B$. maximowicziana populations were evaluated using RAPDs to obtain fundamental 
Table 1. - Location and number of samples collected for each of the four populations of Betula maximowicziana.

\begin{tabular}{|c|c|c|c|c|}
\hline Population & Latitude $(\mathrm{N})$ & Lomgitude (E) & Altitude (m) & number of samples \\
\hline Chichibu (CCB) & $35^{\circ} 56^{\prime}$ & $138^{\circ} 49^{\prime}$ & $1100-1350$ & 20 \\
\hline Mitomi (MTM) & $35^{\circ} 52^{\prime}$ & $138^{\circ} 42^{\prime}$ & $1650-1850$ & 24 \\
\hline Hayakawa (HYK) & $35^{\circ} 20^{\prime}$ & $138^{\circ} 17^{\prime}$ & $1450-1550$ & 24 \\
\hline Furano (FRN) & $43^{\circ} 28^{\prime}$ & $142^{\circ} 46^{\prime}$ & $400-650$ & 25 \\
\hline
\end{tabular}

genetic information for conservation and management of this natural genetic resource.

\section{Materials and Methods}

Study site and plant material

Four natural populations of B. maximowicziana were sampled (Table 1). The Chichibu (CCB) population in University Forest in Chichibu, The University of Tokyo, in Saitama prefecture, and the Mitomi (MTM) and Hayakawa (HYK) populations in Yamanashi prefecture are all located in central Honshu, while the Furano (FRN) population, is located in University Forest in Hokkaido, The University of Tokyo (Figure 1). The three populations in central Honshu are in mixed forest stands with deciduous broad-leaved trees and conifers such as Acer mono, Betula grossa, Fagus crenata, Fagus japonica, Quercus crispula, Abies veitchii and Tusga diversifolia. The FRN population is also in a mixed forest with species such as Abies sachalinensis, A. mono, Betula ermanii, Picea jezoensis, Q. crispula and Tilia japonica.

Fresh branches were sampled randomly from 18-25 individuals for each population. In total, 94 samples were collected (Table 1), and the branches were stored at $-80^{\circ} \mathrm{C}$ prior to DNA extraction.

\section{DNA extraction and PCR procedures}

Total genomic DNA was extracted from fresh cambium using a DNeasy Plant mini kit (Qiagen Co. Ltd. Tokyo). PCR reactions were carried out in $10 \mu \mathrm{L}$ volumes containing $10 \mathrm{ng}$ of genomic DNA, $200 \mu \mathrm{M}$ each of dATP, dCTP, dGTP and dTTP, $1 \times$ buffer, $2.5 \mathrm{mM} \mathrm{MgCl}_{2}, 0.5$ units of Stoffel Fragment DNA

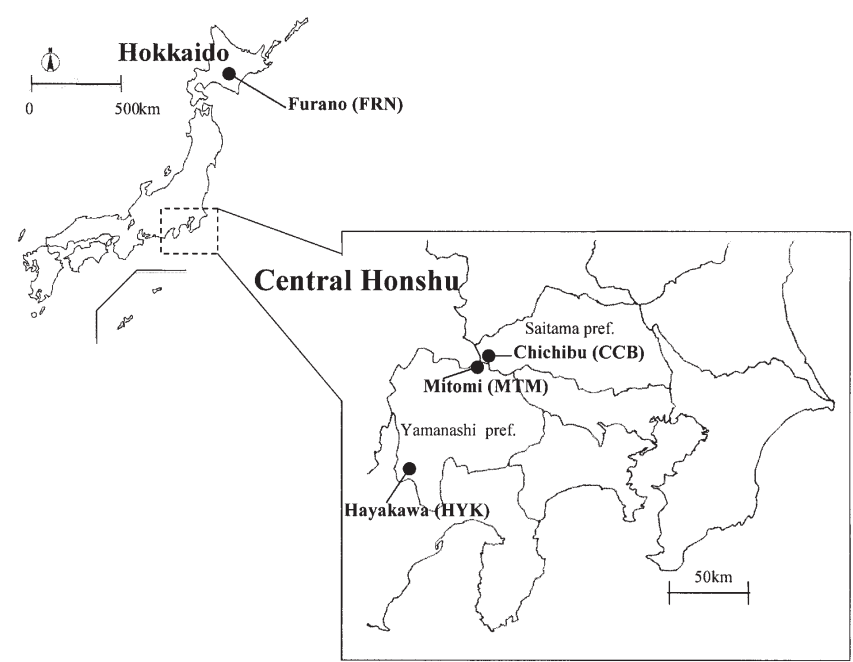

Figure 1. - Sampling site of Betula maximowicziana in Yamanashi, Saitama pref. and Hokkaido.
Taq polymerase $(\mathrm{ABI})$ and $0.5 \mu \mathrm{M}$ of each primer. Samples ware amplified in a DNA thermal cycler (Takara Co. Ltd. Tokyo) programmed to provide a denaturation step at $94^{\circ} \mathrm{C}$ for $5 \mathrm{~min}$, followed by 45 cycles of $94^{\circ} \mathrm{C}$ for $10 \mathrm{~s}, 36^{\circ} \mathrm{C}$ for $30 \mathrm{~s}$, $72^{\circ} \mathrm{C}$ for $1 \mathrm{~min}$ and a final extension step at $72^{\circ} \mathrm{C}$ for $7 \mathrm{~min}$. The amplified products were separated on $2 \%$ agarose gels in $1 \times$ TBE buffer (Takara Co. Ltd. Tokyo) and subjected to electrophoresis. Gels were then stained with ethidium bromide and photographed on a UV transilluminator.

\section{Primer screening}

Two hundred and seventeen primers derived from an Operon 10-mer kit (Qiagen Co. Ltd. Tokyo) were screened in small samples to check the reproducibility and polymorphisms of the RAPD fragments they yielded using more than three runs for each primer.

\section{Data analysis}

RAPD phenotypes for each primer were scored as present (1) or absent (0) for each individual. We only compared these $1 / 0$ data, and did not analyze them assuming Hardy-Weinberg equilibrium following the approach of LYNCH and MilLigaN (1994), because we did not know whether the populations used in this study were in Hardy-Weinberg equilibrium. Genetic variation within the populations was estimated in terms of Shannon's indices (LEWONTIN, 1972) using the program POPGENE version 1.31 (YEH et al., 1999), from the formula:

$$
-\Sigma_{p i} \log _{2 p i}
$$

where $p i$ is the frequency of amplified bands among individuals of each population. Shannon's index is suitable for analyzing RAPD data because of its insensitivity to the bias that can be introduced into data by the inability to detect heterozygous individuals (DAwson et al., 1995; GILlies et al., 1997; PARANI and PARIDA, 1997; Gustafson et al., 1999; MAKI and HoRIE, 1999; OIKI et al., 2001; AGA et al., 2003). Genetic variation was also evaluated by analysis of molecular variance (AMOVA) (EXCOFFIER et al., 1992) using the program GenALEx (PEAKALL and Smouse, 2001). Although AMOVA was originally designed for haploid mitochondrial DNA data (ExCOFFIER et al., 1992), HuFF et al. (1993) successfully applied it to RAPD data. Since then, AMOVA has been used in many RAPD analyses (e.g. BARTISH et al., 1999; JORDANO and GODOY, 2000). The AMOVA was based on the Euclidean metric of ExCOFFIER et al. (1992). The formula is:

$$
\mathrm{E}=\left\{\varepsilon_{\mathrm{xy}}^{2}\right\}=\mathrm{n}\left[1-2 \mathrm{n}_{\mathrm{xy}} / 2 \mathrm{n}\right]
$$

where $2 n_{x y}$ is the number of markers shared by two individuals ( $\mathrm{x}$ and $\mathrm{y}$ ) and $\mathrm{n}$ is the total number of polymorphic markers (HuFF et al., 1993). This Euclidean metric describes the number of RAPD markers that were not shared by two individuals, because only two RAPD states were recognized: 1 or 0 . The molecular variance within each population was calculated as 
an indicator of intra-population genetic variation. Estimates of the partitioning of the genetic variation among the four populations and among individuals within the populations were initially derived from a global analysis without considering differences in region. However, in hierarchical analysis with AMOVA, the genetic variation was partitioned among regions (Hokkaido and central Honshu), as well as among populations within regions and among individuals within populations (CCB, HYK and MTM). The significance of the variance components was tested by calculating their probabilities, based on 999 random permutations using the program GENALEx (Peakall and Smouse, 2001). The indicator of population genetic differentiation, pairwise $\Phi_{\mathrm{PT}}$ from $\Phi$-statistics (EXCOFFIER et al., 1992; PEAKAll et al., 1995) of AMOVA was calculated, and correlations between pairwise $\Phi_{\mathrm{PT}}$ values and geographic distance were tested by regression analyses. The Euclidean metric was also used as the basis for principal coordinate analysis (PCO) (GowER, 1966), from which graphical relationships between individuals were derived using the program GENALEx (PEAKALl and SMouse, 2001). In addition, pairwise $\Phi_{\mathrm{PT}}$ values were used to generate a neighbor-joining dendrogram using the program Populations 1.2.28 (LANGELLA, 2002).

\section{Results and Discussion}

Sixty-one RAPD markers, generated from 23 out of the 217 primers screened, were selected because their banding patterns were unambiguous and reproducible. The designations and sequences of these 23 primers, together with the size of the monomorphic and polymorphic fragments they generated, are shown in Table 2. Out of the 61 RAPD markers selected, 22 were monomorphic in all samples of the four populations examined and 39 were polymorphic in at least one population (Table 2). However, even the 22 monomorphic RAPD markers in this study are potentially valuable because they may reveal polymorphism in other regions in future studies.

The number of polymorphic loci and Shannon's index for each population are shown in Table 3. The number of polymorphic loci ranged from 29 (FRN) to 31 (CCB and MTM) and averaged 30.3. Shannon's indices ranged from 0.360 (FRN) to 0.460 (MTM), averaging 0.405. In comparison, the range and mean value of the Shannon's indices were $0.349-0.612$ and 0.547, respectively, for 12 populations of the South American conifer Fitzroya cupressoides (AlLNUT et al., 1999), 0.592-0.733 and 0.651 for eight populations of Populus tremuloides (YEH et $a l ., 1995$ ) and $0.301-0.367$ and 0.332 for six populations of the endangered tropical tree Plathymenia reticulate (LACERDA et al., 2001). Compared with these previous studies, the withinpopulation genetic variation of $B$. maximowicziana appears to be moderate. Molecular variance within the populations we sampled ranged from 4.870 (MTM) to 5.187 (FRN), averaging 5.017. LACERDA et al. (2001) detected a strong correspondence between Shannon's indices and molecular variance within populations, i.e. populations with the highest Shannon's indices had the highest molecular variance and vice versa. In contrast, while the numbers of polymorphic loci and Shannon's indices in our study indicated a tendency for the genetic variation of the FRN population to be a little lower than that of the populations in central Honshu, the within-population molecular variance of FRN was slightly higher than that of the Honshu populations

Table 2. - Designations, sequences and size of monomorphic and polymorphic fragments generated by the primers.

\begin{tabular}{|c|c|c|c|}
\hline Primer & Sequence ( $5^{\prime}$ to $\left.3^{\prime}\right)$ & Monomorphic fragment size (bp) & Polymorphic fragment size (bp) \\
\hline OPA-10 & GTGATCGCAG & - & 410 and 470 \\
\hline OPA-17 & GACCGCTTGT & 460 & 800,850 and 920 \\
\hline OPA-18 & AGGTGACCGT & - & 590,640 and 700 \\
\hline OPC- 08 & TGGACCGGTG & 520 & 700 \\
\hline OPD-19 & CTGGGGACTT & 260 & 580 \\
\hline OPF-14 & TGCTGCAGGT & 550 & 480 and 640 \\
\hline OPG-05 & CTGAGACGGA & 380 & 630,760 and 850 \\
\hline $\mathrm{OPH}-04$ & GGAAGTCGCC & 460 & 510 \\
\hline OPH-14 & ACCAGGTTGG & - & 750 \\
\hline OPH-15 & AATGGCGCAG & 400 and 530 & 800 \\
\hline OPH-18 & GAATCGGCCA & - & 620,810 and 910 \\
\hline OPI-03 & CAGAAGCCCA & 380,490 and 580 & 840 \\
\hline OPI-05 & TGTTCCACGG & - & 590 \\
\hline OPI-11 & ACATGCCGTG & - & 530 \\
\hline OPI-18 & TGCCCAGCCT & 350 and 530 & 580,660 and 780 \\
\hline OPP-14 & CCAGCCGAAC & 750 and 860 & 450 \\
\hline OPS- 07 & TCCGATGCTG & 410 & 620 and 730 \\
\hline OPS-19 & GAGTCAGCAG & 290 & 470 \\
\hline OPV-06 & ACGCCCAGGT & 400 and 450 & 700 \\
\hline OPW-02 & ACCCCGCCAA & 450 and 640 & 760 and 810 \\
\hline OPW-10 & TCGCATCCCT & - & 550 and 630 \\
\hline OPX-14 & ACAGGTGCTG & 450 & 580 \\
\hline OPX-16 & CTCTGTTCGG & - & 380 and 550 \\
\hline
\end{tabular}


Table 3. - Number of polymorphic loci, Shannon's index I (LEwontin, 1972) and variance within each of the four population.

\begin{tabular}{lccc}
\hline Population & Number of polymorphic loci & Shannons's index & varience \\
\hline CCB & 31 & 0.410 & 5.124 \\
MTM & 31 & 0.460 & 4.870 \\
HYK & 30 & 0.392 & 4.888 \\
FRN & 29 & 0.360 & 5.187 \\
mean & 30.3 & 0.405 & 5.017 \\
\hline
\end{tabular}

Table 4. - Analysis of molecular variance (AMOVA) for 93 individuals grouped in four populations from two regions. The degrees of freedom (d.f.), sum of squares (SS), mean squares (MS), variance components, the total variation contributed by each component $(\%)$ and its associated significance $(n=999$ permutations $)$ are shown.

\begin{tabular}{|c|c|c|c|c|c|c|}
\hline $\begin{array}{c}\text { Source of } \\
\text { variation }\end{array}$ & d.f. & SS & MS & $\begin{array}{c}\text { variance } \\
\text { components }\end{array}$ & $\begin{array}{c}\text { total } \\
\text { variance }(\%)\end{array}$ & $P$-value \\
\hline \multicolumn{7}{|l|}{ Global } \\
\hline Among populations & 3 & 80.064 & 26.688 & 0.933 & 15.6 & $<0.001$ \\
\hline \multicolumn{7}{|l|}{ Among individuals } \\
\hline within population & 89 & 448.087 & 5.035 & 5.035 & 84.4 & $<0.001$ \\
\hline \multicolumn{7}{|l|}{ Hierarchical } \\
\hline Among region & 1 & 43.286 & 43.286 & 0.1038 & 10.4 & $<0.001$ \\
\hline \multicolumn{7}{|l|}{ Among populations } \\
\hline within region & 2 & 36.777 & 18.389 & 0.0942 & 9.4 & $<0.001$ \\
\hline \multicolumn{7}{|l|}{ Among individuals } \\
\hline within population & 89 & 448.087 & 5.035 & 0.802 & 80.2 & $<0.001$ \\
\hline
\end{tabular}

(Table 3). Furthermore, the range of number of loci, Shannon's indices and the molecular variance within populations appeared to be relatively limited. These results suggest that the populations used in this study have very similar levels of within-population genetic variation.

According to the global AMOVA analysis there was significant partitioning of the genetic variation $(\mathrm{P}<0.001)$, with $15.6 \%$ occurring among populations and within-population variation accounting for the remaining $84.4 \%$ (Table 4). The among-population value of the indicator of genetic differentiation, $\Phi_{\mathrm{PT}}$, for the four populations was 0.156 , suggesting that genetic differentiation of $B$. maximowicziana was moderate and that within-population variation accounted for most of the genetic variation of $B$. maximowicziana. Similar tendencies for most genetic variation to be partitioned within-population have been found in several previous studies of tree species involving AMOVA analysis based on RAPDs. For example, $84 \%$ of the total genetic variation detected was within-population for four populations of Abies (three populations of Abies alba and a population of A. nebrodensis) (VICARIO et al., 1995), 97.4\% for eight populations of Populus tremuloides (YEH et al., 1995), 63\% for six populations of Pseudotsuga menziesii (AAGAARD et al., 1998), $87.7 \%$ for six populations of Plathymenia reticulate (LACERDA et al., 2001), 85.6\% for 12 populations of Fitzroya cupressoides (ALLNUT et al., 1999) and $80.2 \%$ for 37 populations of Eucalyptus globulus (NESBITT et al., 1995). The findings of the cited studies, and the study reported here are consistent with conclusions published in reviews of isozyme data (HAMRICK and GoDT, 1989; HAMRICK et al., 1992), showing that long-lived, outcrossing tree species with a wide and continuous range generally retain most of their genetic variation within populations.

According to the hierarchical AMOVA analysis, the amount of genetic variation partitioned among regions and among populations was $10.4 \%$ and $9.4 \%$, respectively, with the remainder

Table 5. - Pairwise $\Phi_{\mathrm{PT}}$ (above diagonal) and geographic distance (bellow diagonal : $\mathrm{km}$ ) between populations.

\begin{tabular}{ccccc}
\hline Population & 1 & 2 & 3 & 4 \\
\hline 1 CCB & - & 0.120 & 0.080 & 0.172 \\
2 MTM & 12.5 & - & 0.119 & 0.219 \\
3 HYK & 85.0 & 70.0 & - & 0.190 \\
4 FRN & 870.0 & 880.5 & 951.5 & - \\
\hline
\end{tabular}

$\ldots$ each pairwise $\Phi_{\mathrm{PT}}$ value was significant $(\mathrm{P}<0.001)$. 
(80.2\%) occurring within-population. NESBITT et al. (1995) found $3.5 \%$ of total genetic variation among regions in a study of RAPD variation of 31 Eucalyptus globules ssp. globules populations situated in Victoria and Tasmania, Australia. Compared with the findings of NESBITT et al. (1995), the genetic variation among regions we found $(10.4 \%)$ is higher than might be expected, since gene flow among $B$. maximowicziana populations is thought to be relatively substantial as it is a widely distributed, outcrossing, wind-pollinated and wind-dispersed species. This somewhat high value of genetic variation partitioning among regions reflects the regional genetic differentiation between the FRN population and the other three populations.

The pairwise $\Phi_{\mathrm{PT}}$ values and geographic distances between the four populations are shown in Table 5. The pairwise $\Phi_{\mathrm{PT}}$ values ranged from 0.080 (CCB and HYK) to 0.219 (MTM and FRN) and each of the pairwise $\Phi_{\mathrm{PT}}$ values was significant according to tests based on 999 random permutations $(\mathrm{P}<0.001)$. In addition, significant correlation between pairwise $\Phi_{\mathrm{PT}}$ and geographic distances was found in the regression test $(\mathrm{r}=0.904, \mathrm{P}<0.05)$, suggesting that geographic distance influences genetic variation.

The first three principal coordinates derived from the principal coordinate analysis (PCO) based on the Euclidean metric for the sampled individuals of the four populations described $13.8,10.5$ and $8.9 \%$ of the total variance. Plots of the first two coordinates are shown in Figure 2. The plots of the three popu-

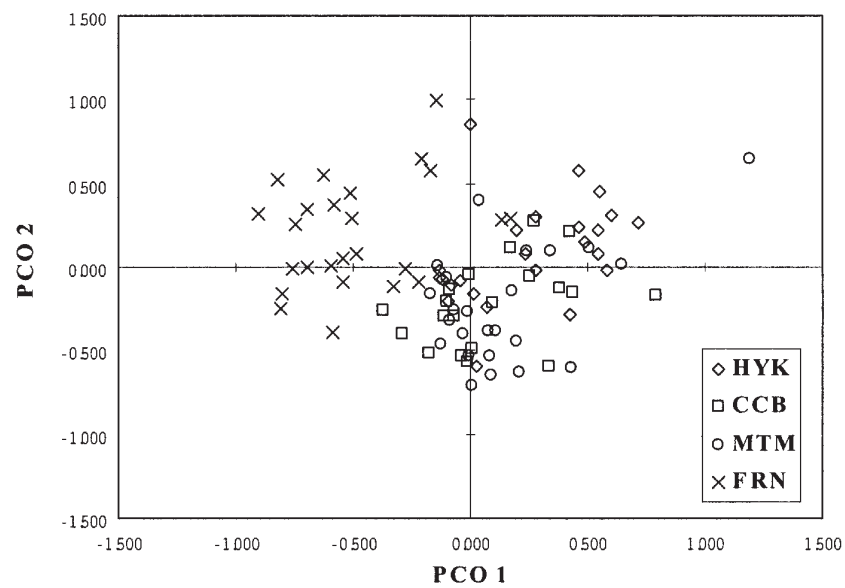

Figure 2. - Plot of the first two principal coordinates for each individual of four populations.

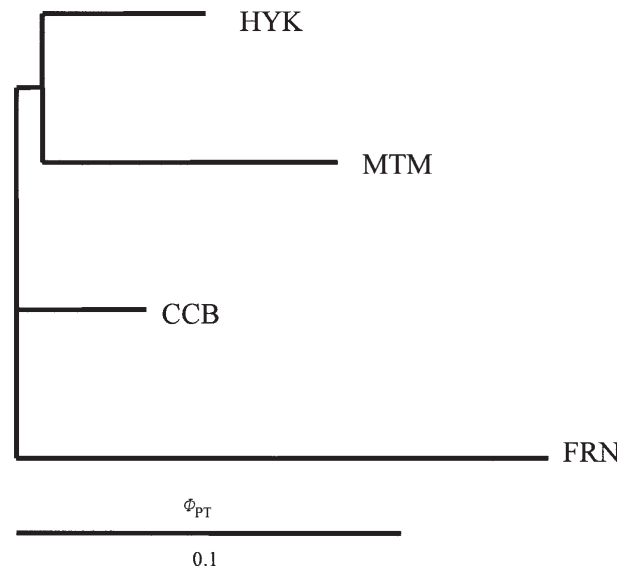

Figure 3. - Neighbour-joining dendrogram based on pairwise $\Phi \mathrm{PT}$ among four populations of B. maximowicziana. lations in central Honshu were closer to one another, or overlapped, than to the FRN population. The neighbor-joining dendrogram based on pairwise $\Phi_{\mathrm{PT}}$ values among populations is shown in Figure 3. The results from the PCO and the neighborjoining dendrogram revealed the same pattern, i.e. that the three populations in central Honshu (CCB, MTM and HYK) are genetically close to each other and differ from the FRN population, which is located about $870-950 \mathrm{~km}$ away from them. These results also agree with the findings of the hierarchical AMOVA analysis, indicating that the among-region genetic variation was somewhat high. Although a significant correlation between geographic distance and genetic distance was detected, other factors that may influence genetic differentiation like gene flow, wind-pollination, the wind-dispersal of B. maximowicziana seeds and the effects of the glacial episodes of the Holocene should also be considered. In addition, B. maximowicziana has a seed bank, which may play compensational roles in years immediately following poor seed years (OSUMI and SAKURAI, 1997), and thus influence genetic variation.

FRN population is geographically distant from the other three populations, and the Tsugaru Straits (known as the "Blakiston line") separates Hokkaido and Honshu. However, there were no unique markers that could distinguish these two regions. This might also be considered to be indicative of moderate genetic differentiation among populations, since RAPD markers that are unique to certain regions or populations isolated by geographic factors have been reported in other species (KANETANI et al., 1994; MosSELER et al., 1992).

In conclusion, fundamental genetic information concerning natural populations of $B$. maximowicziana was obtained using RAPDs in this study and geographic or regional patterns in genetic variation among populations were detected. These genetic findings have important implications for the conservation and management of regional genetic variation of this valuable natural genetic resource. To obtain detailed genetic information facilitating the conservation and management of forest ecosystems containing $B$. maximowicziana, wide-ranging and fine-scale analysis using molecular markers will be required in future studies.

\section{Acknowledgements}

We thank Dr. K. SEIDo and Mr. H. Nishikawa of the Yamanashi Forest Research Institute and Mr. Y. KATO of The University of Tokyo for their help in sampling the plant material, and Dr. H. YoshimARU of FFPRI for statistical advice.

\section{References}

AdACHI, M., SATo, A., Ito, T. and Konno, T. (1980): Stand density and growth progression of a second growth stand of Betula. Trans. Meet. Hokkaido Br. Jpn. For. Soc. 28: 23-25. (in Japanese).

AAgAaRd, J. E., Krutovskit, K. V. and Strauss, S. H. (1998): RAPDs and allozymes exhibit similar levels of diversity and differentiation among populations and races of Douglas-fir. Heredity 81: 69-78.

Aga, E., Bryngelsson, T., Bekele, E. and Salomon, B. (2003): Genetic diversity of forest arabica coffee (Coffee arabica L.) in Ethiopia as revealed by random amplified polymorphic DNA (RAPD) analysis. Hereditas 138: 36-46.

Allnutt, T. R., Newton, A. C., Lara, A., Premoli, A., Armesto, J. J., VERGRA, R. and GARDNER, M. (1999): Genetic variation in Fitzroya cupressoides (alerce), a threatened South American conifer. Mol. Ecol. 8: 975-987.

Bartish, IV., JepPsson, N. and Nybom, H. (1999): Population genetic structure in the dioecious pioneer plant species Hippophae rhamnoides investigated by random amplified polymorphic DNA (RAPD) markers. Mol. Ecol. 8: 791-802. 
Dawson, I. K., Simons, A. J., Waugh, R. and Powell, W. (1995): Diversity and genetic differentiation among subpopulations of Gliricidia sepium revealed by PCR-based assays. Heredity 74: $10-18$.

Excoffier, L., Smouse, P. E. and QuATTro, J. M. (1992): Analysis of molecular variance inferred from metric distance among DNA haplotypes: Application to human mitochondrial DNA restriction data. Genetics 131: 479-491.

GEBUREK, T. (1997): Isozyme and DNA markers in gene conservation of forest trees. Biodiversity and Conservation 6 $1639-1654$

Gillies, A. C., Corneliun, J. P., Newton, A. C., Navarro, C., HERNÁNDEZ, M. and WiLSON, J. (1997): Genetic variation in Costa Rican populations of the tropical timber species Cedrela odorata L., assessed using RAPDs. Mol. Ecol. 6: $1133-1145$.

Gower, J. C. (1966): Some distance properties of latent root and vector methods used in multivariate analysis. Biometrika 53: $325-338$.

Gustafson, D. J., Gibson, D. J. and Nickrent, D. L. (1999): Random amplified polymorphic DNA variation among remnant big bluestem (Andropogon gerardii Vitman) populations from Arkansas' Grand Prairie. Mol. Ecol. 8: 1693-1701.

HAMrICK, J. L. and GoDT, M. L. W. (1989): Allozyme diversity in plant species. In: Plant Population Genetics, Breeding, and Genetic Resource. Edited by Brown, A. H. D., CleGG, M. T., Kahler, A. L. and Weir, B. S., Sinauer. Associates, Inc. Sunderland, Massachusetts. Pp. 43-63.

Hamrick, J. L., Godt, M. J. W. and Sherman-Broyles, S. L. (1992): Factors influencing levels of genetic diversity in woody plant species. New For. 6: 95-124.

HASEGAWA, M. (1998): Effect of weeding and salvage cutting on Monarch birch (Betula maximowicziana Regel) growing in Japanese cedar (Cryptomeria japonica D. Don) plantations in snowy regions. J. Jpn. For. Soc. 80: 223-228. (in Japanese with English abstract).

HASEgawa, M. and TAIRA, H. (2000): The characteristics of species composition of the hardwoods established on Cryptomeria japonica plantations in heavy snow regions. J. Jpn. For. Soc. 82: 28-33. (in Japanese with English abstract).

Holsinger, K. T., Lewis, P. O. and Dey, D. K. (2002): A Bayesian approach to inferring population structure from dominant markers. Mol. Ecol. 11: 1157-1164.

Huff, D. R., Peakall, R. and Smouse, P. E. (1993): RAPD variation within and among natural populations of outcrossing buffalograss [Buchoë dactyloides (Nutt.) Engelm]. Theor. Appl. Genet. 86: 927-934.

JoRDANO, P. and GoDOY, J. (2000): RAPD variation and population genetic structure in Prunus mahaleb (Rosaceae), an animal-dispersed tree. Mol. Ecol. 9: 1293-1305.

Kado, E., Sawada, H., Igarashi, Y., Kabaya, H. and Ide, Y. (2002): Allozyme variations in Betula maximowicziana Regel. populations at Chichibu mountains. Bull. Tokyo Univ. For. 107: 93-98. (in Japanese with English abstract).

Kanetani, S., Watanabe, A., Shiraishi, S., Gyokusen, K. and SAITo, A. (1997): Study on genetic variation of Melia azedarch Linn. populations in Kyushu area using RAPD markers. Bull. Kyushu Univ. For. 70: 1-9. (in Japanese with English abstract).

LANGella, O. (2002): Populations 1.2.28: Population genetic software (individuals or populations distances, phylogenetic trees). France. http://www.cnrs-gif.fr/pge/bioinfo/populations/ index.php?lang $=$ en\&doc $=$ populations.

Lacerda, D. R., Acedo, M. D. P., Lemos Filho, J. P. and Lovato, M. B. (2001): Genetic diversity and structure of natural populations of Plathymenia reticulata (Mimosoideae), a tropical tree from the Brazilian Cerrado. Mol. Ecol. 10: $1143-1152$.

LEWONTIN, R. C. (1972): The apportionment of human diversity. Evolutionary Biology 6: 381-398.
Lynch, M. and Milligan, B. G. (1994): Analysis of population genetic structure with RAPD markers. Mol. Ecol. 3: 91-99.

MAKI, M. and HORIE, S. (1999): Random amplified polymorphic DNA (RAPD) markers reveal less genetic variation in the endangered plant Cerastium fisherianum var. molle than in the widespread conspecific $C$. fisherianum var. fisherianum (Caryophyllaceae). Mol. Ecol. 8: 145-150.

Mosseller, A., EgGer, K. N. and Hughes, G. A. (1992): Low level of genetic diversity in red pine confirmed by random amplified polymorphic DNA markers. Can. J. For Res. 22: $1332-1337$.

Nesbitt, K. A., Potts, B. M., Vaillancourt, R. E., West, A. K. and REID, J. B. (1995): Partitioning and distribution of RAPD variation in a forest tree species, Eucalyptus globulus (Myrtaceae). Heredity 74: 628-637.

OнwI, J. (1965): Flora of Japan. Shinbundo, Tokyo, 1566 pp. (in Japanese).

Oiki, S., Kawahara, T., Inoue, K., Ohara, M. and Maki, M. (2001): Random amplified polymorphic DNA (RAPD) variation among populations of the insular endemic plant Campanula microdonta (Campanulaceae). Annals of Botany 87: 661-667.

OSUMI, K. and SAKURAI, S. (1997): Seedling emergence of Betula maximowicziana following human disturbance and the role of buried viable seeds. For. Ecol. Mange. 93: 235-243.

PARANI, M. and PARIDA, A. (1997): Allozyme and RAPD polymorphism in Tylophora indica (Brum. f.) Merr. Journal of plant Biochemistry and Biotechnology 6: 29-33.

Peakall, R., Smouse, P. E. and Huff, D. R. (1995): Evolutionary implications of allozyme and RAPD variation in diploid populations of dioecious buffalograss Buchloë dactyloides. Mol. Ecol. 4: 135-147.

Peakall, R. and Smouse, P. E. (2001): GENALEx V5.1: Genetic analysis in Excel. Population genetic software for teaching and research. Australian National University. Canberra. Australia. http://www.anu.edu.au/BoZo/GenAlEx/.

Petit, R. J., Mousadik, A. E. and Pons, A. O. (1998): Identifying populations for conservation on the basis of genetic markers. Conservation Biology 12: 844-855.

RAMSer, J., LóPez-Peralta, C., Wetzel, R., Weising, K. and KAHL, G. (1996): Genomic variation and relationships in aerial yam (Dioscorea bulbifera L.) detected by random amplified polymorphic DNA. Genome 39: 17-25.

Saito, Y., Shiraishi, S., Tanimoto, T., Yin, L., Watanabe, S. and IDE, Y. (2002).: Genetic diversity of Populus euphratica in northwestern China determined by RAPD DNA analysis. New For. 23: 97-103

Schierenbeck, K. A., Skuupski, M., Lieberman, D. and LieberMAN, M. (1997): Population structure and genetic diversity in four tropical tree species in Costa Rica. Mol. Ecol. 6: 137-144.

Vicario, F., Vendramin, G. G., Rossi, P., Lio, P. and Giannini, R. (1995): Allozyme, chloroplast DNA and RAPD markers for determining genetic relationships between Abies alba and the relic population of Abies nebrodensis. Theor. Appl. Genet. 90: $1012-1018$

WATANABE, S. (1989): Silvical characteristics of Betula maximowicziana. Forest tree breeding of Hokkaido 32: 15-18. (in Japanese).

Williams, J. G. K., KubeliK, A. R., LivaK, K. L, RAFAlski, J. A. and TingeY, S. V. (1990): DNA polymorphisms amplified by arbitrary primers are useful as genetic markers. Nucleic Acids Res. 18: 6531-6553.

Yeh, F. C., Chong, D. K. X. and YAng, R.-C. (1995): RAPD variation within and among natural populations of trembling aspen (Populus tremuloides Michx.) from Alberta. Journal of Heredity 86: 454-460.

YeH, F. C., YANG, R. and Boyle, T. (1999): POPGENE: Microsoft Windows-based freeware for population genetic analysis. Release 1.31. University of Alberta. Canada. http://www.ualberta.ca/ fyeh/index.htm. 